\title{
Contribution to the Lepidoptera Fauna of Hatay (Turkey)
}

\author{
Erol Atay 1,a,*, Mahmut Tatlı,b \\ ${ }^{1}$ Department of Biology, Faculty of Arts and Sciences, Mustafa Kemal University, 31060 Hatay, Turkey \\ ${ }^{2}$ Institute of Science, Mustafa Kemal University, 31060 Hatay, Turkey
}

*Corresponding author

\begin{tabular}{l|l}
\hline A R T I C L E I N F O & A B S T R A C T \\
\hline Research Article & $\begin{array}{l}\text { Field studies were carried out in the localities of different altitudes and vegetation covers in the } \\
\text { Hatay province in March-October 2018. Papilio demoleus was caught with insect net in the citrus } \\
\text { orchards at Antakya and Reyhanl1. Cornifrons ulceratalis, Macaria alternata and Camptogramma } \\
\text { bilineatum were caught mercury vapour light trap and white screen in different localities, at different } \\
\text { elevations, in different climatic conditions, plant cover and sutface features in Erzin. Papilio } \\
\text { demoleus } \text { was caught in the citrus gardens in the province of Hatay Reyhanl1 district as a male and } \\
\text { a female on 05.09.2018 and in Antakya district on 15.10.2018 as two male and three female } \\
\text { individuals. This invasive species is widespread all over the world and has the potential to create } \\
\text { Accepted : }: 16 / 04 / 2019 \\
\text { substantial threat for citrus orchards in the Mediterranean region and in the eastern Mediterranean } \\
\text { region of Turkey in next years. As a result, Papilio demoleus (Papilionidae), Cornifrons ulceratalis } \\
\text { (Crambidae), Macaria alternata and Camptogramma bilineatum (Geometridae) are new records for } \\
\text { the lepidoptera fauna of Hatay. }\end{array}$ \\
$\begin{array}{l}\text { Keywords: } \\
\text { Papilio demoleus } \\
\begin{array}{l}\text { Cornifrons ulceratalis } \\
\text { Macaria alternata }\end{array}\end{array}$
\end{tabular}

Macaria alternata

Camptogramma bilineatum

Hatay

Citrus

Türk Tarım - Gıda Bilim ve Teknoloji Dergisi 7(5): 719-723, 2019

\section{Hatay’ın (Türkiye) Lepidoptera Faunasına Katkılar}

\begin{tabular}{|c|c|}
\hline M A K A L E B İ L G İ S İ & Ö Z \\
\hline $\begin{array}{l}\text { Geliş : :05/11/2018 } \\
\text { Kabul : 16/04/2019 } \\
\\
\text { Anahtar Kelimeler: } \\
\text { Papilio demoleus } \\
\text { Cornifrons ulceratalis } \\
\text { Macaria alternata } \\
\text { Camptogramma bilineatum } \\
\text { Hatay } \\
\text { Turunçgil }\end{array}$ & $\begin{array}{l}\text { Mart-Ekim } 2018 \text { tarihleri arasında Hatay ilinde yapılan bu çalışma farklı yüksekliklerde ve farklı } \\
\text { bitki örtüsüne sahip lokalitelerde gerçekleştirilmiştir. Papilio demoleus Antakya ve Reyhanlı } \\
\text { ilçelerindeki narenciye bahçelerinde atrap yardımıla yakalanmıştır. Cornifrons ulceratalis, } \\
\text { Macaria alternata ve Camptogramma bilineatum Erzin ilçesinde farklı iklim koşullarında ve farkl1 } \\
\text { yüksekliklerdeki bitki örtüsüne sahip lokalitelerden 1şı tuzağ1 ve beyaz perde yardımıyla } \\
\text { yakalanmıştır. Papilio demoleus Reyhanlı ilçesindeki narenciye bahçelerinden } 05.09 .2018 \text { tarihinde } \\
\text { bir erkek ve bir dişi birey ve Antakya ilçesindeki narenciye bahçelerinden ise } 15.10 .2018 \text { tarihinde } \\
\text { iki erkek ve üç dişi birey yakalanmıştır. Bu istilacı tür birçok ülkede yaygındır ve gelecek yıllarda } \\
\text { da Akdeniz ve Doğu Akdeniz Bölgelerindeki turunçgiller için önemli bir tehdit potansiyeline } \\
\text { sahiptir. Sonuç olarak, Papilio demoleus (Papilionidae), Cornifrons ulceratalis (Crambidae), } \\
\text { Macaria alternata ve Camptogramma bilineatum (Geometridae) Hatay'ın Lepidoptera faunası için } \\
\text { yeni kayıt türlerdir. }\end{array}$ \\
\hline
\end{tabular}




\section{Introduction}

The first attempt on the checklist of the Turkish moths was listed by Koçak and Kemal (2006, 2007). Totally 4604 moth species were listed together with their synonymous named and updated provincial distributions. Later, the authors (Koçak and Kemal, 2018), reported that the Turkey Lepidoptera fauna was 5577 species (5158 moths and 412 butterfly) belonging to 76 families ( 9 butterfly, 67 moth families). In addition, a total of 508 lepidoptera species, 377 Heterocera and 131 Rhopalocera, belonging to the province of Hatay were listed by the same authors.

Papilio demoleus Linnaeus, 1758 (Lepidoptera, Papilionidae) (Figure 1,2) is a common pest of all citrus plants (Koçak et al., 2008; Suwarno, 2012; Wiemers, 2012; Yazdani et al., 2014; Lewis, 2018). The lime swallowtail, $P$. demoleus, is sometimes called the chequered or citrus swallowtail. This butterfly ranges widely and an extremely successful invader. Its proliferation appears to be aided by agricultural land use and urbanization that create new, suitable, open habitat and enhanced availability of resources (Lewis, 2018). The most striking character of this species among the other papilionid species is the absence of tail at the hindwing (Koçak et al., 2006). There are six subspecies of the butterfly in the world: these are; Papilio demoleus demoleus Linnaeus, 1758 (Across Asia from China to the Arabian Peninsula, and in some islands in the West Indies, including Jamaica), $P$. d. libanius Fruhstorfer, 1908 (Taiwan, Philippines, Sula, Talaud), P. d. malayanus Wallace, 1865, (Sumatra and the Malaysian peninsula), $P$. d. novoguineensis Rothschild, 1908 (Papua New Guinea),
P. d. sthenelus Macleay, 1826 (Australia), P. d. stenelinus Rothschild, 1895 (Sumba, Flores and Alor) (Wiemers, 2012). P. demoleus is an economic pest on many cultivated citrus species in India, Pakistan, China, Nepal, Japan, Iraq, Arabian Peninsula, Australia, Dominican Republic, Turkey, Syria and the Middle East (Benyamini et al., 2007; Tshikolovets, 2011; Wiemers, 2012; Lewis, 2018). Due to its capability for rapid population growth under favourable circumstances and its having been recorded to have five generations in a year in temperate regions of China, it is considered a serious potential threat (Homziak and Homziak, 2006).

According to Wiemers (2012), until recently, Papilio demoleus was thought to be a species confined to warm climates, and that a climatic barrier was limiting its further north westward expansion from the Arabian Peninsula into the Mediterranean Region. The recent records indicate that $P$. demoleus might be a more adaptive species which can acclimatize in regions with slightly different conditions and colonize the citrus plantations there. Some authors associate the $P$. demoleus range extension with recent climatic warming in the Northern Hemisphere that move the climatic borders previously limiting the species distribution.

In this study is aimed to give systematic information about Papilio demoleus (Papilionidae), Cornifrons ulceratalis (Crambidae), Macaria alternata and Camptogramma bilineatum (Geometridae) species which are new records for Hatay province.

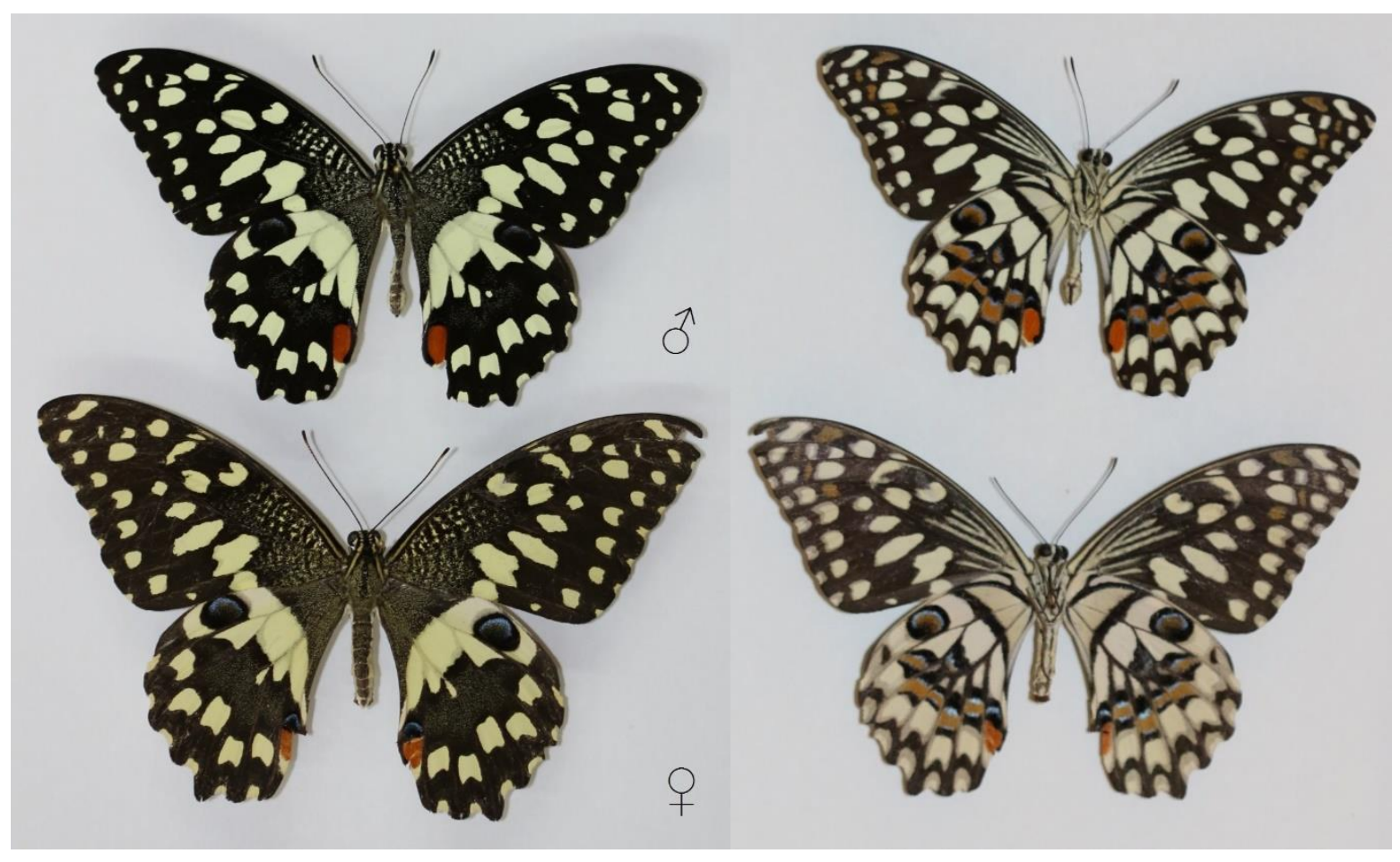

Figure 1 Dorsal and ventral views of adults, Papilio demoleus 


\section{Material and Methods}

\section{Field Studies}

Field studies were carried out in the localities of different altitudes and vegetation covers in the Hatay province in March-October 2018. All the field works were done under suitable weather conditions (without precipitation and strong winds) and started early in the morning and continued until sunset. Papilio demoleus Linnaeus was caught with insect net in the citrus orchards at Antakya and Reyhanl. Cornifrons ulceratalis Lederer, Macaria alternata [Denis\&Schiffermüller] and Camptogramma bilineatum (Linnaeus) were caught mercury vapour light trap and white screen in different localities, at different elevations, in different climatic conditions, plant cover and surface features in Erzin.

\section{Laboratory Studies}

Before losing body water, the collected specimens were sorted according to body sizes, and were needed with number 0 and 2 insect needles that matched the size of the custom sized boards, strain and inhibition couples were strained in laboratory work. For the drying of the stretched specimens, they were kept at room temperature for two weeks in a dark and dry place. Male and female genital organs of species (Cornifrons ulceratalis, Macaria alternata and Camptogramma bilineatum) were prepared for the identification The needling of the butterflies, stretching of the wings and genital organ preparations were done accordingly the methods that defined in Atay's work (2006). The specimens stored at the Biology Department of Mustafa Kemal University in Hatay.

\section{Results}

Papilio demoleus Linnaeus, 1758 Papilionidae

(Figs. 1, 2)

Syn: demoleus L., 1758; erithonius Cramer, [1782]; epius Fabricius, 1793; sthenelus Macleay, 1826; demoleinus Oberthür, 1879; pictus Fruhstorfer, 1898; chryseis Boullet \& Le Cerf, 1912; flavosignatus Heydemann (Koçak et all, 2006).

Materials examined: Reyhanl-Hatay (36 $06^{\circ} 26^{\prime \prime} \mathrm{N}$; 3608'39" E, 350 m.) 05.IX.2018 1ð, 1 9 ; Antakya-Hatay (3607'26” N; 3608'39” E, 350 m.), 15.X.2018 20, 3 ‥

Wingspan $\delta^{\lambda}: 90 \mathrm{~mm}$, $+100 \mathrm{~mm}$; Body Length $\delta^{\lambda}: 27$ $\mathrm{mm}$,,$: 26 \mathrm{~mm}$. 2009).

The distribution in Turkey: Mardin (Koçak and Kemal,

Cornifrons ulceratalis Lederer, 1858 (Crambidae; Evergestinae)

(Fig. 3)

Syn: ulceratalis Lederer, 1858; Scoparia seriziatalis Oberthür, 1876 (Koçak and Kemal, 2018).

Materials examined: Erzin-Hatay (36 07'26" N; 3608'39” E, 350 m.) 20.VII.2018 2亏, 1 क; 12.VIII.2018 $2 \sigma^{\circ}$.

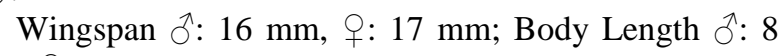
$\mathrm{mm}$, . $: 6 \mathrm{~mm}$.

The distribution in Turkey: Antalya, Gaziantep, Van (Koçak and Kemal, 2009).

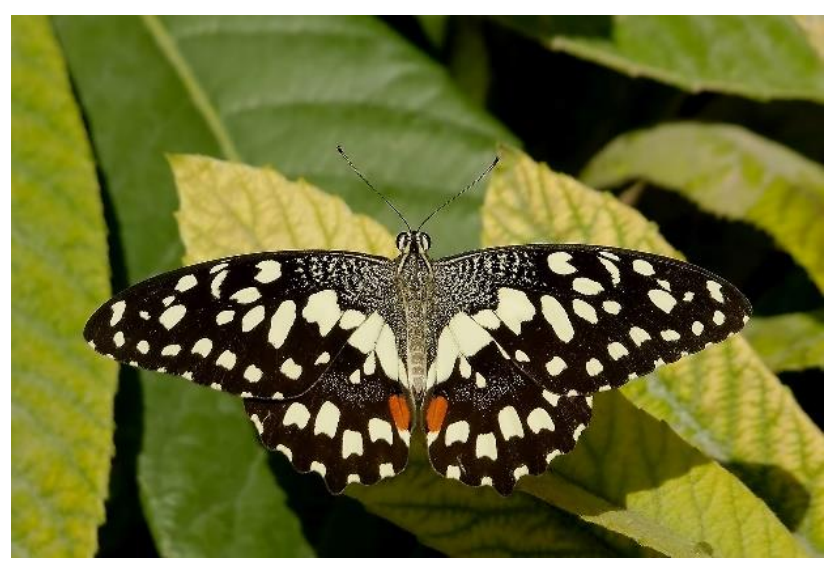

Figure 2 Dorsal view of adult, Papilio demoleus

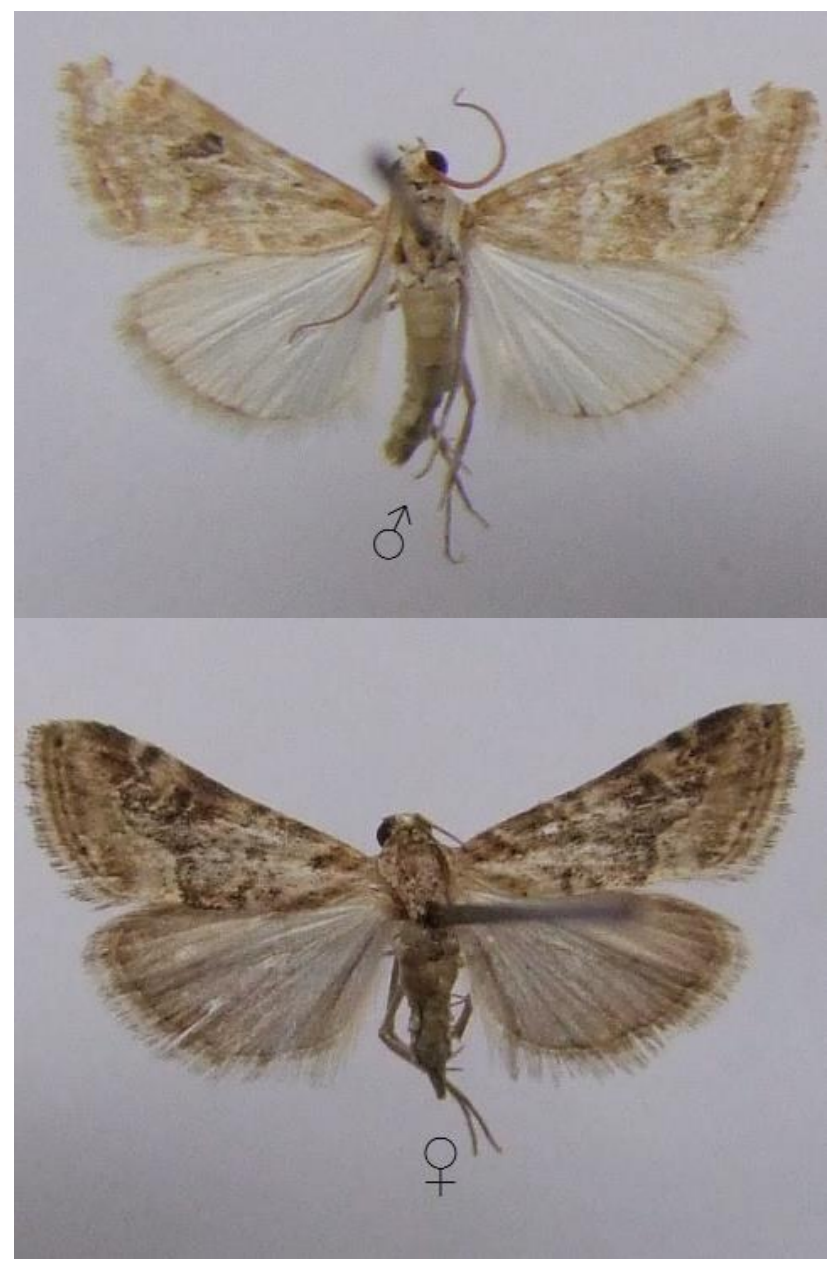

Figure 3 Dorsal view of Cornifrons ulceratalis (Male and female)

\section{Macaria alternata [Denis\&Schiffermüller, 1775]} (Geometridae)

(Fig. 4)

Syn: alternata [Denis\&Schiffermüller, 1775]; alternaria Hübner, [1805]; praenotata Haworth, 1809 (Koçak and Kemal, 2018).

Materials examined: Erzin-Hatay $\left(36^{\circ} 07^{\prime} 26^{\prime \prime} \mathrm{N}\right.$; 3608’39” E, 350 m.) 20.VII.2018 1; 12.VIII.2018 1ð.

Wingspan $\widehat{\jmath}: 30 \mathrm{~mm}$, 吕: $30 \mathrm{~mm}$; Body Length $\widehat{\jmath}: 11$ $\mathrm{mm}$, $: 11 \mathrm{~mm}$.

The distribution in Turkey: Bursa, Kahramanmaraş (Koçak and Kemal, 2009). 


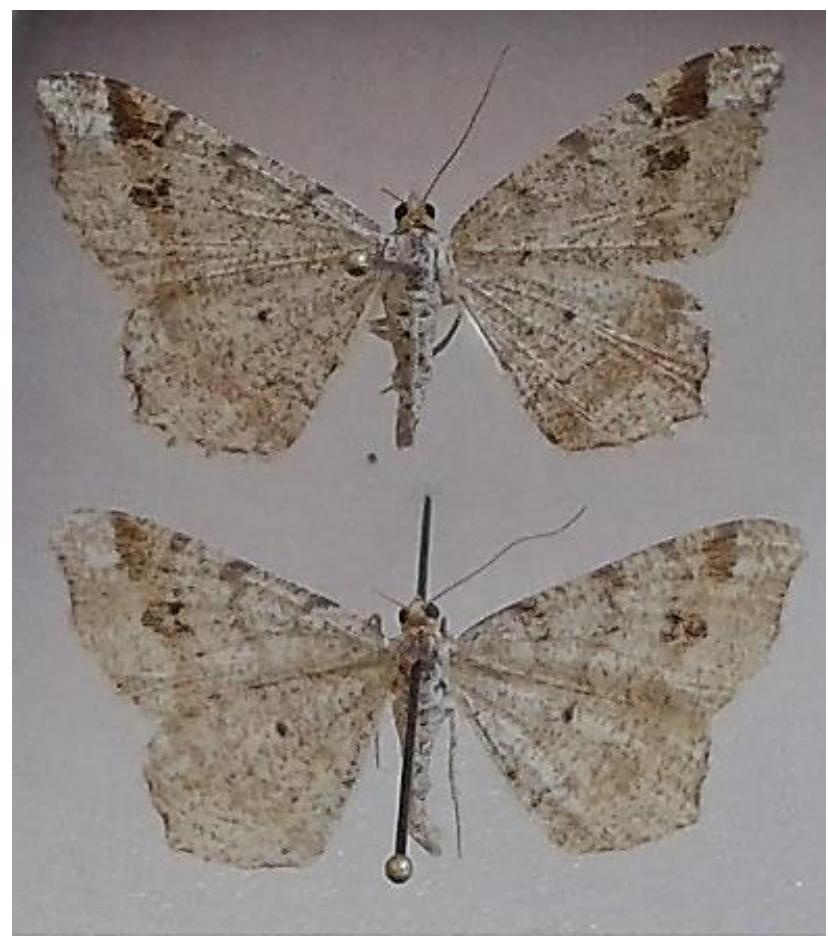

Figure 4 Dorsal view of Macaria alternata (Male and female)

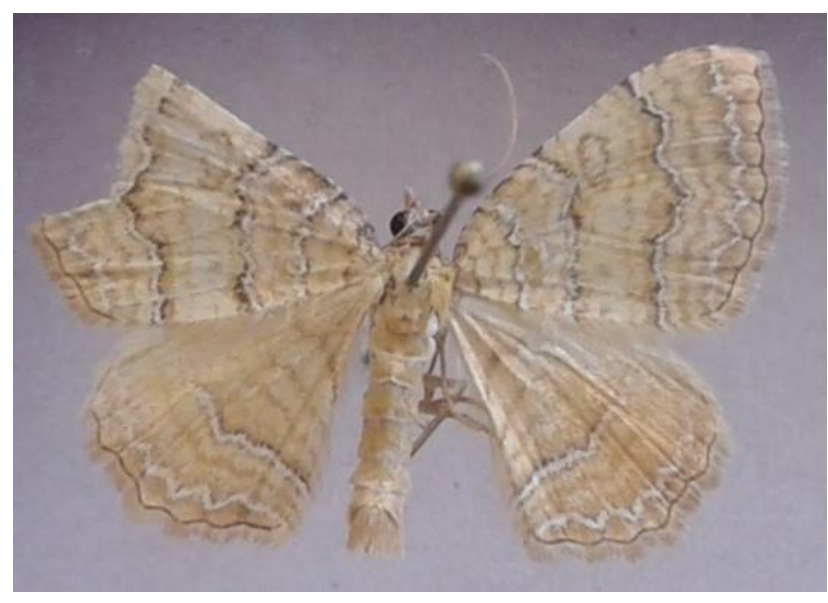

Figure 5 Dorsal view of Camptogramma bilineatum (Male)

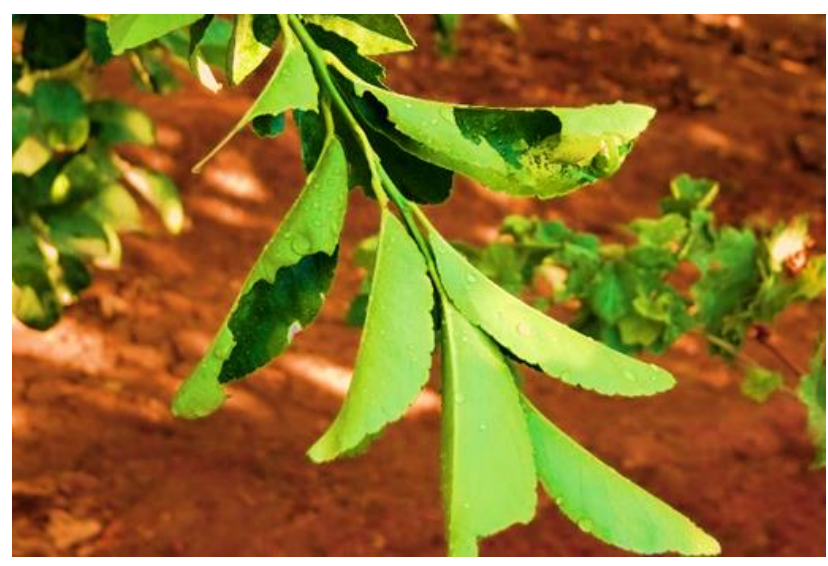

Figure 6 The Larvae damages on Citrus leaves
Camptogramma bilineatum (Linnaeus, 1758) (Geometridae)

(Fig. 5)

Syn: bilineata L., 1758; brocatella Fourcroy, 1785; dumetata Schrank, 1802; bilinearia Boisduval, 1840; musauria Freyer, 1846; testaceolata Staudinger, 1871 (Koçak and Kemal, 2018).

Materials examined: Erzin-Hatay $\left(36^{\circ} 07^{\prime} 26^{\prime \prime} \mathrm{N}\right.$; 3608'39” E, 350 m.) 12.VIII.2018 1ठ․

Wingspan $\delta^{\wedge}: 23 \mathrm{~mm}$; Body Length $\sigma^{\lambda}: 11 \mathrm{~mm}$.

The distribution in Turkey: Adana, Adiyaman, Amasya, Ankara, Balıkesir, Bitlis, Bolu, Bursa, Çanakkale, Hakkari, Kars, Ordu, Tokat, Van, Şırnak (Koçak and Kemal, 2009).

As a result, Papilio demoleus L. (Papilionidae), Cornifrons ulceratalis Lederer (Crambidae), Macaria alternata [Denis\&Schiffermüller] (Geometridae) and Camptogramma bilineatum (Linnaeus) (Geometridae) are new record for the lepidoptera fauna of Hatay.

\section{Discussion}

Papilio demoleus demoleus reported a new record by Koçak et al., (2006) for the first time in Nusaybin district of Mardin in Turkey. This species was caught in the citrus gardens 13 years later for first time which in the province of Hatay Reyhanl district as a male and a female on 05.09.2018 and in Antakya district on 15.10.2018 as two male and three female individuals.

This species, which is an important citrus pest (Fig. 6) and migrant, has probably reached to Reyhanli district of Hatay province through Syria and from there to the Antakya where is another district of Hatay province. There are significant citrus cultivation in the city of Hatay and there are orange, lemon, mandarin and grapefruit gardens of citrus species in Antakya, Samandağ, İskenderun, Dörtyol and Erzin districts. A total of 643.533 tons of products are received from citrus orchards, which are approximately 205.835 decares in Hatay. In Turkey where production made from Adana, Mersin, Hatay, Antalya and Mugla province is 1.277.426 decares and in total 3.681.158 tons of citrus production is made from garden. This invasive species is widespread all over the world and has the potential to create substantial threat for citrus orchards in the Mediterranean region and in the eastern Mediterranean region of Turkey in next years.

\section{References}

Benyamini D, Bruschini C, Serra G, John E. 2007. First confirmed records of Papilio demoleus (Linnaeus 1758) in Syria, with comments on the species' appearance in Turkey and the Dominican Republic. News the Israeli Lepidoterists Scoiety, 24: 1-7.

Homziak NT, Homziak J. 2006. Papilio demoleus (Lepidoptera: Papilionidae): A New Record for The United States, Commonwealth of Puerto Rico. Florida Entomologist, 89: 485-488.

Koçak AÖ, Kemal M, Akdeniz İ. 2006. A new genus and species to the Lepidoptera fauna of Turkey and Syria (Papilionidae). Miscellanous Papers Centre for Entomological Studies, 97: 16. 
Koçak AÖ, Kemal M. 2006. Checklist of the Lepidoptera of Turkey. Miscellanous Papers Centre for Entomological Studies, 1: 1-196.

Koçak AÖ, Kemal M. 2007. Revised and annotated checklist of the Lepidoptera of Turkey. Miscellanous Papers Centre for Entomological Studies, 8: 1-150.

Koçak MK, Akdeniz İ. 2008. On the Early Stages of Princeps demoleus (Linnaeus,1758) in South East Turkey (Lepidoptera, Papilionidae). Miscellanous Papers Centre for Entomological Studies, 2: 9-13.

Koçak AÖ, Kemal M. 2009. Revised checklist of the Lepidoptera of Turkey. Miscellanous Papers Centre for Entomological Studies, 17: 1-150.

Koçak AÖ, Kemal M. 2018. A synonymous and distributional list of the species of the Lepidoptera of Turkey. Miscellanous Papers Centre for Entomological Studies, 8: 1-489.
Lewis DS. 2018. Lime swallowtail Papilio demoleus Linnaeus (Insecta: Lepidoptera: Papilionidae). IFAS Extension University of Florida. 1-5.

Suwarno J. 2012. Age-specific life table of swallowtail butterfly Papilio demoleus (Lepidoptera: Papilionidae) in dry and wet seasons. Biodiversitas, 13: 28-33.

Tshikolovests VV. 2011. Butterflies of Europe \& the Mediterranean area. Tshikolovets Publications. pp. 544.

Wiemers M. 2012. First records of the Lime Swallowtail Papilio demoleus Linnaeus, 1758 (Lepidoptera, Papilionidae) in Europe. The Journal of Research on the Lepidoptera, 45: 8589.

Yazdani E, Zibaee A, Sendi JJ. 2014. Digestive proteoses of Papilio demoleus: comportmentalization and characterization. Phytoparasitica, 42: 121-133. 